\title{
Cotidiano e trabalho no bairro do Bexiga: uma hipótese a ser pensada (I906-I93I)
}

[ Everyday life and work in a quarter of Bexiga: a chance to be thought (I906-I93I)

\section{Sheila Schneck ${ }^{\mathrm{I}}$}

RESUMO No processo de expansão urbana sofrido pela cidade de São Paulo desde a segunda metade do século XIX, decorrente do desenvolvimento da economia cafeeira e da inserção do estado de São Paulo no mercado exportador, iniciativas orientadas por um zoneamento e especialização de usos e funções foram adotadas com o objetivo de adequar a capital paulista ao novo papel. Assim, parte das moradias e de segmentos do comércio, oficinas, fábricas e serviços menos nobres deslocaram-se em direção aos bairros vizinhos ao perímetro central. Este ensaio se propõe a conhecer e compreender de que maneira o bairro do Bexiga se inseriu no movimento de reespacialização social e das funções urbanas - seu papel na reconfiguração da cidade -, assim como suas conexões com o espaço urbano mais amplo. PALAVRAS-CHAVE • São Paulo; urbanização; bairros; trabalho; funções. • ABSTRACT · In the process of urban expansion suffered by the city of São Paulo since the second half of the Igth century, due to the development of the coffee economy and the insertion of the state of São Paulo in the exporting market-driven initiatives and expertise of zoning uses and functions have been adopted with the aim to adapt the state capital to the new role. So, part of housing and of segments of commerce, workshops, factories and services less noble gravitated towards the nearby neighborhoods to the central perimeter. This essay aims to know and understand how the Bexiga if entered in reespacialização social movement and urban functions-its role in the reconfiguration of the city - as well as their connections with the wider urban area. KEYWORDS · São Paulo; urbanization; neighborhoods; job; functions.

Recebido em 5 de abril de 2016

Aprovado em 4 de outubro de 2016

SCHNECK, Sheila. Cotidiano e trabalho no bairro do Bexiga: uma hipótese a ser pensada (I906I93I). Revista do Instituto de Estudos Brasileiros, Brasil, n. 65, p. 72-95, dez. 2016.

DOI: http://dx.doi.org/ro.II6o6/issn.23I6-90IX.voi65p72-95

I Universidade de São Paulo (USP, São Paulo, SP, Brasil). 
A dinamização da economia paulista em decorrência da cultura cafeeira e sua exportação para o mercado internacional, entre as últimas décadas do século XIX e as primeiras do século XX, implicou a redefinição do papel da cidade de São Paulo em relação à Província e ao mundo urbanizado e industrializado, incrementando as atividades produtivas secundárias e terciárias locais. Disso resultou a reordenação dos espaços físicos da cidade, nos quais passaram a ser exercidas certas atividades em detrimento de outras, orientadas por um zoneamento e especialização de usos e funções explícitos e implícitos na legislação. Nesse movimento, novos bairros foram abertos, ocupando, inicialmente, as áreas mais próximas do centro e, em seguida, outras mais afastadas.

Se desde os tempos coloniais, até aproximadamente a década de I860, as construções da cidade concentravam moradias e negócios indistintamente, a partir da Primeira República, com o consequente processo de expansão da malha urbana é que se observa a reordenação dos espaços. Atividades que até então se realizavam no centro da cidade, assim como parte de seus habitantes, foram obrigadas a se dispersar, buscando novos locais para morar e exercer atividades indesejadas na área central. O bairro do Bexiga formou-se numa daquelas áreas próximas do centro da cidade, respondendo à demanda por moradias para grupos médios e baixos da população e à demanda por certos tipos de comércio, serviços e manufaturas.

Embora o objeto deste ensaio seja o microcosmo de um bairro, qualquer tentativa de compreensão de um espaço destacado do todo poderá resultar em visões distorcidas da realidade. Por outro lado, na utilização de diferentes escalas no estudo do território, a escolha de uma dimensão não exclui a importância da outra já que ambas respondem a pontos de vista diferentes, porém complementares ${ }^{2}$. Em nosso caso, o pano de fundo do trabalho é dado por um processo comum às duas escalas, a macro e a micro. Sob o ponto de vista da história urbana, a primeira fornece as dimensões políticas, econômicas e culturais que incidiram sobre a tessitura material e social do espaço urbano como um todo; e a segunda, ao focar um bairro específico, procura expor como aquele espaço vivenciou o processo mais amplo, e como os traços que lhe são peculiares incidiram sobre a escala macro, num movimento de contínua

2 LEPETIT, Bernard. Por uma nova história urbana. São Paulo: Edusp, 200I, p. 2I3-2I6. 
interação. É nesse sentido que buscamos compreender o papel desempenhado pelo bairro do Bexiga no processo mais amplo vivenciado pela cidade de São Paulo.

Os primeiros sinais de ocupação do bairro datam de I882, quando a construção das primeiras casas indicava a viabilidade do empreendimento que aos poucos se concretizaria. Simultaneamente, os primeiros negócios foram instalados e, em I906, a presença de quitandas, armazéns de secos e molhados, açougues, jogos de bola, padarias e oficinas demonstra que o bairro já apresentava certo amadurecimento de suas práticas produtivas. Levando-se em conta a confirmação efetiva dos usos no espaço - moradia e trabalho - e por meio dos indícios sugeridos pelas fontes documentais, o ano de 1906 foi utilizado como baliza inicial de trabalho.

O processo de modernização e expansão urbana iniciado na segunda metade do século XIX atingiu seu ápice em fins dos anos I920, até a Revolução de I930. As consequências desse processo, ainda que os usuários do bairro não tenham se envolvido diretamente nos acontecimentos, estão implícitas nos depoimentos de personagens que por ali circularam, atestando o início de um novo momento no qual usos e práticas se tranformaram, delineando os traços do espaço que deu origem ao que hoje compreendemos como o grande distrito da Bela Vista, mais comumente conhecido como "Bixiga". Diante das inequívocas transformações operadas naquele território, envolvendo rupturas e permanências, elegemos o ano de I930 como baliza final do trabalho.

Tendo em vista o intenso processo de transformação sofrido pela cidade no decorrer do século XX, envolvendo demolições, construções de viadutos, abertura de novas vias, assim como a mudança dos paradigmas culturais que marcaram a região, e, consequentemente, as dificuldades do olhar contemporâneo em separar o bairro (do Bexiga) do distrito (da Bela Vista), é necessário definir o foco espacial desta abordagem. Tomando como ponto de partida o Largo do Riachuelo, local que marcava a fronteira do Bexiga com o Centro, contemplamos aquela que foi a área do loteamento original do bairro - delimitada pelas ruas Santo Antônio, Treze de Maio, Avenida Brigadeiro Luís Antônio e Rua Santo Amaro -, sem contudo ignorar parte do que se convencionou chamar de Bela Vista. Nesse sentido, a região do Vale da Saracura, cujo início da ocupação, ainda que rarefeita, antecedeu o empreendimento original, forçosamente deve ser incluída na análise. As águas e ribanceiras do córrego, ao interpor barreiras físicas ao deslocamento dos moradores, estabeleceram um segundo limite físico do bairro. Por fim, uma terceira área somou-se às anteriores, por contiguidade, e corresponde às ruas abertas pela Baronesa de Limeira alinhadas ao loteamento original 3 . Tratava-se, por suas dimensões, de um espaço restrito, sujeito a ser envolvido pelo caráter mais amplo dado pela ocupação do loteamento vizinho

3 Trata-se do arruamento empreendido em I894, em terras que pertenciam à antiga Chácara do Barão de Limeira, entre o Largo do Riachuelo e a Av. Brigadeiro Luís Antônio. O arruamento envolveu, além da Av. Brigadeiro Luís Antônio, parte da Rua Asdrúbal do Nascimento, as ruas Maria Paula, Genebra, Francisca Miquelina, Aguiar de Barros e pequeno trecho da Jaceguai. SÃO PAULO (Município). Acto n. Io, de I 4 de maio de I894, que "Aceita e dá denominação às ruas abertas pela Baronesa de Limeira em sua chácara à rua do Riachuelo”. Câmara Municipal de São Paulo. Legislação. Disponível em: <http://documentacao.camara.sp.gov. br/iah/fulltext/actos/AooIo-I894.pdf >. Acesso em: 20 jun. 2016. 
- a Liberdade - que, de acordo com as plantas elaboradas entre I905 e I9244, tinha limites imprecisos entre as ruas Tamandaré e Glicério e a Av. Brigadeiro Luís Antônio. Por sua vez, a Avenida Brigadeiro Luís Antônio, artéria do loteamento da Baronesa de Limeira, pela sua condição articuladora do Centro, da Liberdade e do sul da cidade, estruturou-se numa tríplice função de local de atividades produtivas, de ocupação humana e via de acesso, representando a verdadeira fronteira, aí entendida no sentido metafórico de lugar de "encontros" e não de barreira física, tal como definido por Peter Burke5, entre os bairros do Bexiga e da Liberdade.

Definidos os limites físicos da área em questão, trata-se de conhecer e compreender de que maneira o bairro se inseriu no movimento de redefinição dos espaços produtivos e sociais da cidade ao abrigar parte das atividades deslocadas do centro. Mais precisamente, trata-se de definir o papel desempenhado pelo bairro e, consequentemente, por seus moradores num mercado de trabalho frequentemente informal. Ainda que ali tenham se realizado atividades produtivas aparentemente "menores" do ponto de vista da macroeconomia, com pequenos estabelecimentos comerciais e de serviços, elas certamente foram fundamentais para o funcionamento do todo, na medida em que os negócios ali abertos tinham um papel específico no processo de reespacialização das funções urbanas. Ali se instalaram pessoas de pequenas e médias posses, assim como o comércio mais simples voltado ao abastecimento alimentar e à prestação de serviços menos especializados, apresentando a coexistência entre moradia e trabalho.

Entre I906 e I9I4, o número de negócios direcionados ao abastecimento alimentar apontava para um fenômeno, no mínimo, curioso: nada menos do que 76 quitandas identificadas na Série Alvará e Licença do Arquivo Histórico de São Paulo (AHSP)', número aparentemente desproporcional para o bairro. Levando-se em conta que esse era um tempo em que as pessoas não tinham como conservar produtos perecíveis, a presença de vários desses estabelecimentos numa mesma rua, muitas vezes distantes poucos metros entre si, leva ao questionamento de quem seriam os possíveis consumidores dos produtos ali comercializados.

A busca de resposta a essa questão resultou na hipótese de que a clientela potencial para os produtos vendidos nas quitandas não estivesse vinculada apenas

4 Planta geral da cidade de São Paulo, I905, adoptada pela Prefeitura Municipal para uso de suas repartições. Levantada e organisada pelo Engenheiro Civil Alexandre Mariano Cococi e Luiz Fructuoso F. Costa, Engenheiros da Commissão Geog. e Geologica. Acervo Biblioteca Nacional. Disponível em: <http://objdigital. bn.br/objdigital2/acervo_digital/div_cartografia/cart523225/cart523225.jpg〉; Planta da cidade de S. Paulo mostrando todos os arrabaldes e terrenos arruados, I924. Prefeitura de São Paulo. Secretaria Municipal de Desenvolvimento Urbano. Histórico demográfico do município de São Paulo. Disponível em: 〈http://smdu. prefeitura.sp.gov.br/historico_demografico/img/mapas/I924.jpg >. Acesso em: 20 jun. 2016.

5 BURKE, Peter. O que é história cultural?. 2. ed. Rio de Janeiro: Zahar, 2008, p. I53.

6 Duas séries documentais do Arquivo Histórico de São Paulo foram fundamentais para a compreensão das transformações ocorridas na cidade, entre o final do século XIX e início do XX. A primeira - Alvará e Licença - contém os processos de solicitação de licença para a abertura de negócios comerciais e/ou de serviços. Já a segunda - Obras Particulares - envolve os requerimentos encaminhados à Diretoria de Obras do Município visando à concessão de licença para a construção, demolição ou reforma de prédios. 
aos moradores do Bexiga, mas também se encontrasse fora dos limites do bairro. Nesse sentido, o depoimento de alguns memorialistas que escreveram sobre a cidade naquele período forneceu indícios significativos. Foi o caso, por exemplo, de Jorge Americano, que em suas memórias dedicou um capítulo inteiro aos vendedores ambulantes que circulavam pelas ruas dos Campos Elíseos. Hipoteticamente, entre os inúmeros personagens listados pelo autor, alguns poderiam ser originários do Bexiga: o leiteiro, a carroça de verduras, a carroça do padeiro, o homem que vendia frangos, o fruteiro, o caixeiro do armazém, o baleiro, o sorveteiro etc.7.

O Bexiga era um território encravado entre os bairros ocupados pelas camadas médias e altas da população - o Morro dos Ingleses, a Liberdade, o Paraíso, a Avenida Paulista e, desde os anos I920, a Vila América. Com exceção da Liberdade e do Paraíso, marcados por uma mescla de usos residenciais e comerciais, os demais bairros possuíam um caráter exclusivamente residencial. Parece bastante razoável a ideia de que a localização do Bexiga em relação a esses bairros colocasse os negócios de comércio de alimentos em situação privilegiada. Outro aspecto marcante do bairro corrobora essa hipótese: as inúmeras cocheiras presentes nas ruas do Bexiga, identificadas na Série das Obras Particulares (AHSP), utilizadas como uma espécie de estacionamento, abrigando carroças e animais, essenciais para o transporte de pessoas e mercadorias. As 80 cocheiras identificadas entre I905 e I923 (Série Obras Particulares do AHSP) sinalizam que parte dos veículos ali guardados servia à distribuição de alimentos comercializados em quitandas e armazéns do próprio bairro do Bexiga, possivelmente voltadas ao fornecimento dos bairros lindeiros.

É importante destacar que uma análise mais consistente das práticas de sobrevivência dos usuários do bairro alerta para aspectos imperceptíveis a um primeiro olhar, os quais envolvem diferenças na própria distribuição espacial e humana do bairro. Daí a necessidade de aprofundamento dos aspectos que atribuíam especificidades às três áreas distintas, sucintamente descritas acima, fruto das interfaces que estabeleciam com áreas lindeiras, verificando a heterogeneidade de espaços e atores num bairro aparentemente homogêneo. Identificam-se assim as várias faces de um bairro e de seus usuários e a distribuição dos diferentes espaços de trabalho, rua a rua. Os levantamentos realizados junto às fontes primárias permitiram constatar que a configuração assumida pelo bairro extrapolava os limites dados pelo loteamento original. Pelo menos desde I9Io, quando da criação do distrito da Bela Vista, os limites do antigo Bexiga (con)fundiram-se com as áreas contíguas ao Vale da Saracura (entre o leito da atual Av. 9 de Julho e a Rua Santo Antônio) e ao arruamento empreendido pela Baronesa de Limeira (entre a Rua Santo Amaro e a Av. Brigadeiro Luís Antônio), gerando espaços diferenciados. Mais do que a ampliação do espaço físico, esse alargamento territorial implicou a apropriação por atividades distintas.

Resta saber o que as pessoas que moravam no Bexiga faziam para sobreviver e que tipo de ocupação possuíam. Entre todas as ocorrências apontadas nos Boletins

7 AMERICANO, Jorge. São Paulo naquele tempo (I895-I9I5). 2. ed. São Paulo: Carrenho Editorial/Carbono I4, 2004, p. IO3-II2. 
de Ocorrência ${ }^{8}$ há uma profusão de ocupações relacionadas a diferentes setores da economia formal ou informal: serviços de alimentação, comércio, manufatura, construção civil, indústria, trabalho doméstico, serviço público, serviços "diversos" etc. Infelizmente, as categorias indefinidas, nas quais se encontram trabalhadores e serviços domésticos, concentram a maior parcela dos casos, tornando impossível uma avaliação mais efetiva. Excetuando-se essas categorias, somente os trabalhadores da construção civil e trabalhadores domésticos obtiveram uma representação mais significativa.

Chama a atenção a pulverização das diferentes ocupações, quaisquer que fossem as atividades principais a que estivessem atreladas. A presença de pessoas que trabalhavam, aparentemente, em todas as áreas em que se precisasse de um profissional, fosse como "oficiais" manufatureiros ou como prestadores de serviços, parece apontar para a situação constatada pelo memorialista Haim Grünspun nos anos I930. Ainda que se leve em conta a distância temporal entre os anos de I9Io e aqueles vivenciados pelo autor, parece ter se mantido a lógica do trabalho masculino no bairro, onde, principalmente os homens, "trabalhavam mais como tarefeiros e de expediente [...] os homens eram ajudantes por dia [...] tarefeiros. Sempre ajudantes de alguma coisa, quer no bairro, quer fora do bairro". Por outro lado, a presença, ainda que em número restrito, de profissionais especializados é um indício de que o Bexiga não era um espaço exclusivo dos setores mais pobres da cidade.

Em relação às pessoas estabelecidas no bairro e envolvidas com algum tipo de comércio ou prestação de serviços, às informações fornecidas pelas solicitações de licenças para a abertura de negócios junto à Prefeitura, acrescem-se os anúncios dos Almanaques mercantis publicados na época. Além dos anúncios em jornais, eram muito comuns os anúncios em almanaques, publicações anuais que divulgavam informações sobre o "comércio, indústria e profissões, com classificação pelos ramos de negócios".

O Almanak Laemmert, publicado na capital da República, fornece um imenso rol

8 Trata-se dos Boletins de Ocorrência do Posto Médico da Assistência Policial, integrantes do Fundo de Segurança Pública, do Arquivo Público do Estado de São Paulo (Apesp). Esse corpus documental é particularmente importante por fornecer uma multiplicidade de dados e detalhes sobre a vida cotidiana dos moradores do bairro - nome, cor, nacionalidade, idade, filiação (quando se tratava de menores de I8 anos), profissão, endereço e motivação da ocorrência. Ao informar as nacionalidades, as profissões desempenhadas pelos atores sociais, sua localização no espaço e as causas das ocorrências, possibilita a remontagem de certos perfis típicos do bairro.

9 GRÜNSPUN, Haim. Anatomia de um bairro. O Bexiga. São Paulo: Cultura, I979, p. 37. 
de atividades ${ }^{\mathrm{Io}}$. Ali, entre a infinidade de negócios estabelecidos no bairro, verifica-se uma variada gama de comércios/serviços e manufaturas. Predominam quitandas, armazéns de secos e molhados e açougues, além de padarias, pequenas "fábricas" de massas alimentícias e de torrefação de café em meio a lojas de vestuário, calçados e chapéus, e as atividades ligadas ao lazer (cinema, teatro e jogos de bola). Destacam-se também manufaturas (sapatos, chapéus, sabões, velas, louças de barro, caixotes, bebidas, cigarros, fogos de artifício etc.) e a prestação de serviços diversos (farmácias, barbearias, sapateiros, costureiras, fotógrafos etc.). No Bexiga também moravam artífices voltados ao ramo da construção civil (fabricantes de ladrilhos e mosaicos, encanadores, carpinteiros, eletricistas, pintores, vidraceiros etc.). Havia ainda casas que vendiam de tudo um pouco, como as lojas de armarinhos e fazendas, de "ferragens e quinquilharias", louças etc., além daquelas atividades destinadas a dar suporte ao próprio comércio e manufaturas em geral.

Esse panorama sucinto revela, ainda que parcialmente, os esforços empreendidos por quem viveu no bairro do Bexiga para ganhar o "pão de cada dia" e garantir, se não um futuro melhor, ao menos a sua sobrevivência diária. Entretanto, não é possível afirmar que tudo sempre correu da melhor maneira possível para todos os envolvidos. A relativa frequência de negócios abertos e fechados em curto espaço de tempo, bem como as mudanças de endereços ou mesmo de proprietários, é um indicador dessa fragilidade. Por vezes, os pedidos de baixa vêm acompanhados das respectivas justificativas, dando chances de compreender o que ocorria. Em Io de fevereiro de I9Io, Generoso Rubino, dono de uma quitanda na Rua Conselheiro Ramalho n. 50, diz que, "tendo em vista não estar vendendo, pede encerramento do negócio" "I. Algo semelhante ocorreu com João Ferraciano, que, em 3 de abril de I907, ao decidir fechar a "fábrica de massas alimentícias" que possuía, na rua Santo Antônio n. 208, por "ter feito pouco negócio com a fábrica, solicita perdão pelos três meses de licença que deve pagar" ${ }^{\text {I2. }}$. Seu caso, inclusive, pode indicar por que tantas "fábricas" encontradas no decorrer de nossas pesquisas raramente aparecem mais de uma vez nos almanaques ou em outros documentos. Embora fossem assim citadas por seus proprietários, tratava-se mais de pequenas manufaturas do que de fábricas propriamente ditas.

Ãs dificuldades de venda, fossem quais fossem os motivos e os produtos oferecidos, acresciam-se os gastos implícitos no exercício do negócio, no mínimo

Io Annuario administrativo, agrícola, profissional, mercantil e industrial dos Estados Unidos do Brasil. O Almanaque Laemmert, nome pelo qual ficou conhecido o anuário, foi publicado primeiramente por iniciativa dos irmãos Laemmert e, posteriormente, por membros dessa mesma família, na cidade do Rio de Janeiro. A publicação, iniciada em I844, após passar por sucessivas crises, chegou até os anos I9I4, quando passou a se chamar Anuário do Brasil. Em I925, o anuário passou a ser editado por membros do Jockey Club do Rio de Janeiro, voltando a ter o nome original, Almanak Laemmert Ltda. O estado de São Paulo conta com volumes especiais, publicados entre I909 e I93I, além de outros anos. ALMANAK LAEMMERT. Editado nas Officinas Typographicas do Almanak Laemmert. Disponível em: 〈http://bndigital.bn.br/hemeroteca-digital〉. Acesso em: 20 jun. 2016.

II Alvará e Licença, Io/2/I9IO, AHSP.

I2 Alvará e Licença, 3/4/I907, AHSP. 
o aluguel do imóvel e os impostos semestrais ou anuais. Se o negócio não gerasse os ganhos esperados, o seu proprietário se veria em dificuldades para saldar os compromissos, o que certamente poderia levá-lo a desistir do empreendimento. No entanto, o fracasso de determinada atividade não significava que não se tentasse buscar outro caminho. Isso aconteceu, por exemplo, com o próprio João Ferraciano, que parece não ter desanimado com o fracasso da sua fábrica de macarrão, pois sete anos depois ele estava instalado com um "armazém de secos e molhados" na Rua Manoel Dutra n. $65^{\mathrm{I} 3}$.

De acordo com o Almanak Laemmert, a exploração de diferentes ramos de negócios no mesmo endereço foi um fato relativamente comum entre os negociantes do Bexiga, principalmente entre I9I3 e I9I4, quando aparecem estabelecimentos onde conviviam armarinhos e fazendas/sapateiro; botequim/fábrica de bonés; barbearia/ secos e molhados; ferreiro/secos e molhados; armarinhos e fazendas/comércio de louças, porcelanas e cristais/ferragens e quinquilharias/secos e molhados; empreiteiros/fábrica de sabão/secos e molhados; empreiteiros/papelaria/tipografia. Essa variedade de combinações tanto podia significar a necessidade de diversificar para atender o maior número possível de pessoas e assim garantir ganhos maiores, quanto demonstrava o espírito empreendedor de seus proprietários. Se uma coisa não desse certo, a outra poderia dar...

No entorno do "perímetro central", bairros como Bom Retiro, Barra Funda, Brás e Mooca ou regiões mais distantes como Lapa e Água Branca passaram a concentrar preferencialmente fábricas, resultando na dualidade de usos, que envolvia trabalho e moradia. Ali, os novos loteamentos realizados por empreendedores para venda e locação mesclaram fábricas e moradia barata. Outros bairros, como o Cambuci e o Bexiga, abrigaram o comércio simples voltado basicamente ao abastecimento alimentar e à prestação de serviços menos especializados, ali existindo raramente grandes fábricas e inexistindo as chamadas "vilas operárias" construídas pelos donos dos estabelecimentos. No Bexiga, predominaram moradias em meio ao comércio miúdo, serviços, oficinas e manufaturas de menor porte. Todavia, em todos esses bairros observamos a coexistência entre moradia e trabalho. Já as camadas altas, ao deixarem o "centro", num primeiro momento fixaram-se nos bairros mais bem localizados a oeste, como Campos Elíseos, por volta dos anos I870, para logo em seguida buscar áreas altas e nobres aos olhos do discurso higienista, como o Morro dos Ingleses, a Avenida Paulista e Higienópolis, áreas de uso exclusivamente residencial.

Foi nesse processo de reordenação urbana, com a realocação de pessoas e atividades produtivas, que se definiram as funções do bairro do Bexiga. Aparentemente, talvez nada de muito significativo em termos da macroeconomia, mas foi justamente a presença dos "pequenos ofícios" que contribuiu para sedimentar o papel da cidade no contexto social, econômico e político mais amplo. Se os bairros fabris se destacaram por abrigar as indústrias que determinariam o futuro da cidade como metrópole progressista, os bairros populares desempenharam um papel secundário, mas não menos importante. Vimos acima uma profusão de pequenos negócios destinados

I3 Alvará e Licença, 23/3/I9I4, AHSP. 
ao comércio de alimentos e de produtos básicos para o abastecimento de moradores do próprio Bexiga e, certamente, dos bairros (mais ricos ou não) localizados nos arredores. Daí, a presença (e importância) das cocheiras para abrigo de veículos e animais que seriam usados na entrega diária de leite, pão, frutas, verduras e outros produtos. Nas oficinas, onde se fazia de tudo um pouco, da fabricação ao conserto de utensílios usados no dia a dia, carpinteiros, marceneiros, encanadores, ferralheiros e vidraceiros não somente forneceram os materiais e a mão de obra necessária para as novas construções, como também viabilizaram a sua manutenção; funileiros e mecânicos consertavam automóveis, os novos veículos utilizados pelas famílias mais ricas; costureiras, alfaiates e sapateiros confeccionavam e consertavam artigos de vestuário e calçados; lavadeiras, cujo ofício, conforme Haim Grünspun, "era uma das profissões mais comuns” no bairro, serviam os moradores do próprio Bexiga, do Morro dos Ingleses e do Paraíso ${ }^{\mathrm{I}}$.

\section{AS ATIVIDADES IDENTIFICADAS}

$\mathrm{O}$ ano de 1906 insere-se num período de configuração física do bairro, quando ocorre o primeiro grande impulso construtivo com a edificação de grande número de prédios destinados a moradia e negócios. Na primeira fase da ocupação efetiva do bairro, entre I893 e I895, foram abertos junto à Diretoria de Obras cerca de 96 processos envolvendo pedidos de licença para alinhamento, construção e/ou reforma de edifícios residenciais e comerciais. Já para o triênio de I905-I906-I907, localizamos I22 solicitações de licença para a construção e/ou reforma de prédios destinados a moradia e negócios.

Naquele ano, quando os anúncios do Almanak Laemmert ainda se concentravam num único volume, foram poucos os anunciantes no bairro do Bexiga, somente II casos. A categoria que abrangeu maior número de assinantes foi aquela ligada à construção civil, superando outras categorias que mais tarde se destacariam, tais como os setores de alimentos e vestuário, fato bastante compreensível já que naquele momento o bairro ainda estava apenas parcialmente ocupado.

No entanto, a ausência de dados no Almanak para 1906 deve ser relativizada. A escassez de anunciantes naquele ano pode se justificar pelo fato de se tratar de um loteamento recente e de ocupação rarefeita, onde, talvez, pouca gente tivesse consciência do alcance de uma publicação destinada à divulgação de atividades econômicas. Por outro lado, naquele momento, a grande maioria dos usuários do bairro, moradores e negociantes, era composta por pessoas de pequenas ou médias posses, cujos empreendimentos apenas estavam começando.

Passados três anos, em I909, o quadro se transforma, com o número de anunciantes chegando a I 36 casos. Nesse ano o número de atividades relacionadas ao setor de alimentação se destaca, com 72 anúncios, representando pouco mais de $52 \%$ do total, tendência essa que se manterá por praticamente todo o período investigado.

Em I9I3, pela primeira vez, o Almanak Laemmert dedicou um volume inteiro ao

I4 GRÜNSPUN, Haim, op. cit., p. 33. 
estado de São Paulo. Nesse período a economia do estado se mostrava em franca ascensão, chegando a competir com a capital federal, o que justifica a iniciativa. De fato, um exame detalhado da publicação demonstra que somente o bairro do Bexiga apresentou 290 anúncios naquele ano, um aumento de aproximadamente II $4 \% \mathrm{em}$ relação a I909.

Em I9I4, esse total chegaria a 376 anúncios, sendo que o setor de alimentação representava $51 \%$ do conjunto. Entre junho e agosto de I9I4, deflagrou-se a Primeira Guerra Mundial, com sérias consequências para a economia mundial e, por extensão, para a economia brasileira. Porém, convém ressaltar, ainda que sucintamente, que o início do conflito só fez piorar uma situação que já estava dada pela própria conjuntura econômica brasileira. Desde I9I3 vinha se desenhando um quadro de recessão na economia do país em razão da queda dos preços dos principais produtos de exportação, particularmente do café e da borracha, ao mesmo tempo que se mantinha o nível de importações, acarretando um grave déficit na balança comercial (o montante a se pagar aos credores externos se mantinha sempre além do que se tinha a receber).

O agravamento da crise após o início da guerra condicionou a paralisação do mercado do café, que, por sua vez, refletiu-se nos setores produtivos nacionais, gerando recessão, alta de preços, redução dos salários e desemprego ${ }^{15}$. A análise das atividades produtivas desenvolvidas no bairro do Bexiga permite constatar em que medida a crise gerada na macroescala se refletiu na microescala do bairro, afetando a vida e os negócios de pessoas comuns, gente que talvez nem compreendesse a exata dimensão do problema, mas que certamente carregou o seu ônus.

Contudo, de acordo com os anúncios divulgados no anuário, as consequências da crise somente foram sentidas a partir do início de $\mathrm{I} 9 \mathrm{I} 5^{\mathrm{I}}{ }^{6}$, quando o anuário registrou apenas 39 anúncios para o bairro do Bexiga. Curiosamente, nesse ano, o setor da saúde, representado por oito médicos e seis farmácias, foi responsável pela maioria dos anúncios publicados - I4 casos, ou aproximadamente $36 \%$ do total de 39 registros -, restando ao setor de alimentação apenas sete registros (dois açougues, quatro padarias e um armazém de secos e molhados). Já a construção civil seria representada pelo anúncio de apenas um engenheiro. No caso dos dois setores é flagrante a presença de anúncios de profissionais liberais. Embora não se saiba exatamente qual a realidade desses profissionais, dificilmente eles estariam isentos das consequências da crise financeira do país. O mais provável é que, justamente por se tratar de um momento de crise, investissem esforços extras na divulgação de seu trabalho.

Com pequenas flutuações, a situação perduraria até I9I8, ano do final do conflito, quando localizamos 134 anúncios. Naquele momento, o setor de alimentação, com 4I anúncios, voltaria a se destacar sobre os demais, seguido pelo da saúde, com 35 anúncios, representando, respectivamente, 30,60\% e 26,II\% desse total. Já o setor da

I5 FAUSTO, Boris. A Revolução de I930. Historiografia e história. 7. ed. São Paulo: Brasiliense, I98I, p. I57-I58.

I6 A publicação do anuário era feita no início do ano, portanto, as informações relativas a I9I4 são anteriores à deflagração do conflito. 
construção civil, com oito anúncios (5,97\%), demoraria ainda algum tempo para se recuperar, perdendo lugar, inclusive, para o setor de vestuário e acessórios (9,7\%).

Vale lembrar ainda que a publicação do anuário acontecia no início do ano, e que a assinatura do armistício ocorreu em novembro de I9I8. Portanto, as tendências de crescimento já estavam dadas havia quase um ano. $O$ fato é que, independentemente das crises geradas pela guerra, nesse momento a economia paulista já mostrava sinais de recuperação, pelo menos no que tange ao espaço do bairro do Bexiga.

No biênio I922-I923 observa-se a retomada do crescimento. Passados quatro anos desde o final da guerra, as atividades ligadas à alimentação mantêm a liderança em relação às demais. Entre os 440 anúncios registrados, I78 deles (40,45\%) se referem a atividades de algum modo vinculadas ao setor, composto quase sempre de açougues, padarias e armazéns de secos e molhados destinados à satisfação de necessidades básicas, mas também de estabelecimentos dedicados ao comércio e serviços que envolviam produtos considerados "supérfluos", tais como confeitarias, confeitos, salsicharias e comércio de vinhos, ou ainda alguns botequins.

Na sequência se destaca o setor de vestuário e acessórios, com 50 anúncios (II,36\%) envolvendo a manufatura e o comércio de roupas, sapatos e chapéus. Também é nesse momento que os anúncios divulgando serviços de caráter pessoal ganham destaque. Do total de 440 anúncios, 46, ou aproximadamente Io\%, se relacionam a algum tipo de serviço, desde aqueles mais básicos, prestados por barbeiros e tintureiros, até aqueles envolvendo profissionais liberais como os advogados.

Nos anos I922-I923, a saúde se mantém como uma das categorias a concentrar um grande número de anúncios de farmácias, médicos, parteiras, dentistas e até um químico. Com 44 registros, o setor representa aproximadamente Io\% dos anunciantes naquele ano.

De modo geral, os dados coletados nesse biênio evidenciam alguns aspectos relevantes. Pela primeira vez desde I9I4, nenhuma das categorias elencadas se apresenta em branco. Mesmo aquelas atividades de menor importância no cenário produtivo demonstram alguma preocupação de divulgação profissional, caso especialmente dos agentes comerciais, do comércio de aparelhos elétricos, máquinas e equipamentos, e das atividades vinculadas à informação e comunicação e à educação. Nesses casos, a introdução de atividades de caráter aparentemente menos essencial (ainda que em número reduzido), que ao menos teoricamente deveriam estar circunscritas ao centro da cidade, parece indicar certa tendência de especialização das atividades no perímetro central, deslocando-se para as áreas envoltórias os estabelecimentos voltados para a venda de maquinário, os pequenos serviços, as oficinas e pequenas manufaturas outrora ali sediadas. De toda maneira, quaisquer conclusões nesse sentido pedem uma análise mais detalhada envolvendo a localização desses negócios, assim como o tempo de permanência naquele espaço. Fato é que os dados relativos aos anos I922-I923 demonstram um amadurecimento do papel representado pelo bairro do Bexiga na economia urbana da cidade de São Paulo.

Entretanto, a insurreição militar de I924, deflagrada em 5 de julho daquele ano, se não interrompeu o ritmo de crescimento da economia paulistana, reduziu drasticamente seu impulso. Um conjunto de fatores decorrentes do conflito afetou 
principalmente os bairros populares. O clima de insegurança diante da ameaça constante dos bombardeios ocorridos em alguns bairros levou parte da população a buscar abrigo no interior paulista, e a população que permaneceu na cidade viu-se diante da escassez de alimentos em virtude da dificuldade de abastecimento. Consequentemente, ocorreram saques em armazéns e depósitos, gerando prejuízos a comerciantes e produtores. Até os últimos anos da década, a recuperação da economia foi parcial, sem nunca atingir o nível alcançado no biênio I922-I923.

Em I927, embora alguns setores (como alimentação, vestuário e acessórios pessoais, comércio de gêneros diversos, serviços pessoais e saúde) mantivessem certo ritmo de crescimento, o total de 495 registros demonstra uma pequena desacelaração em relação ao biênio I922-I923. Se, ali, a ordem de crescimento em relação ao período anterior chegou a mais de $220 \%$, agora o salto seria muito inferior, de pouco mais de $12 \%$. Contudo, ainda que o crescimento tenha sido reduzido, os dados coletados continuam a apontar para a tendência, já esboçada nos anos anteriores, de concentração daqueles setores entre as atividades exercidas no bairro do Bexiga. O mesmo pode ser dito para I93I. Passados quatro anos, os anúncios publicados no Almanak Laemmert totalizaram 604 registros, com um crescimento de 22,02\%.

Na realidade, a perda do impulso de crescimento, registrada entre I9I8 e I923, tem a ver com uma questão mais ampla da economia brasileira, caracterizada pela dependência do setor agrário-exportador, cabendo aos setores secundário (fábricas) e terciário (comércio e serviços) um papel menos relevante. A dependência das exportações do café desde há muito constituía um problema para o país, mas foi a crise gerada pela quebra da Bolsa de Nova York, em I929, que detonou a recessão e o fim de uma fase da economia brasileira. De maneira geral, a queda das exportações e a redução das importações, o fechamento de fábricas e de estabelecimentos comerciais e o consequente desemprego foram o estopim para os enfrentamentos entre os segmentos politicamente atuantes naquele período, que culminariam na Revolução de I930, e nas mudanças políticas e sociais dela decorrentes.

Portanto, os índices apresentados pelos anúncios publicados no Almanak Laemmert no decorrer do período estudado mostram-se coerentes com a realidade econômica e política subjacente à realidade do bairro.

De maneira geral, a análise das informações oriundas do levantamento do Almanak Laemmert indicou aspectos relevantes para a compreensão da evolução das atividades produtivas no bairro do Bexiga:

I. O predomínio dos estabelecimentos voltados para alimentação, incluídas as atividades comerciais e de serviços em relação a outros setores produtivos. Em I9I4, por exemplo, esse segmento foi responsável por aproximadamente $54 \%$ do total de 3IO atividades registradas nas ruas do bairro. Em algumas delas, chegou a compor a quase totalidade dos negócios (caso das ruas Aguiar de Barros, Conselheiro Carrão, Maria Paula, Santo Amaro e do Sol). A exceção ficou por conta da Av. Brigadeiro Luís Antônio, onde o setor de alimentos respondeu por apenas 35,84\% do total de 53 atividades registradas. Trata-se de armazéns de secos e molhados e quitandas, voltados ao abastecimento doméstico de gêneros de primeira necessidade. 
2. A variedade e complexidade do comércio e serviços oferecidos em determinadas ruas, de modo a suprir praticamente todas as necessidades dos moradores do bairro e dos bairros adjacentes. A Rua Conselheiro Ramalho é um dos exemplos mais expressivos desse fenômeno, só superado pela Av. Brigadeiro Luís Antônio. A tendência se acentuou com o passar dos anos. Em I92I, a diversificação de negócios foi acompanhada, ainda que timidamente, pela introdução de serviços mais especializados (livrarias, papelarias, comércio de fotografias e bilhetes postais, comércio de jornais e revistas, editores de livros e músicas, tipografias, serviços de importação e exportação, representantes de casas comerciais, ourives e relojoeiros, professores de violino e piano, afinadores de pianos, modistas e comércio de modas e confecções, alfaiatarias, casas de banho etc.), quase todos até então praticamente exclusivos das ruas do Triângulo (I5 de Novembro, Direita e São Bento). Ao lado desses estabelecimentos, outros menos "charmosos" respondiam às necessidades de produtos e serviços mais simples, porém fundamentais (barbearias, sapatarias, tinturarias, marcenarias, carpintarias, ferreiros, bombeiros hidráulicos, construtores, correarias e selarias, farmácias, parteiras, como também as lojas de armarinhos, fazendas e modas, de materiais de construção, ferragens e quinquilharias, carvão vegetal etc.).

3. A presença de um número considerável de profissionais liberais (professores, engenheiros, advogados, médicos, farmacêuticos, dentistas e até um veterinário) em diversas ruas do bairro, desde o ano de I909, comprova que nesse momento o bairro já se mostrava como um espaço que abrigava diferentes camadas sociais.

4. A conjugação de diferentes tipos de negócios num mesmo endereço, eventualmente sob o comando de um mesmo proprietário.

\section{UM CASO ESPECIAL: AS COCHEIRAS}

O objetivo deste tópico é pensar a questão que fundamenta nossa suposição: até que ponto o comércio varejista de alimentos se dirigia exclusivamente à demanda dos moradores do bairro do Bexiga ou se destinava sobretudo à satisfação das necessidades dos moradores dos bairros vizinhos ou ainda de outras áreas da cidade - pelo número de estabelecimentos comerciais de gêneros de primeira necessidade no bairro é possível supor que as demandas externas eram prioridade, possibilidade que a presença das "cocheiras" ajuda a fundamentar.

Curiosamente, ainda que os lançamentos anuais de impostos sobre atividades indiquem esses estabelecimentos como um tipo de atividade econômica, os almanaques não contêm quaisquer referências às cocheiras. Contudo, as solicitações de licença para construção e/ou reforma das cocheiras na Série Obras Particulares demonstram que sua presença é inquestionável.

A instalação de cocheiras nem sempre era feita em função do abrigo de veículos e animais particulares ou mesmo de um negócio particular de seus proprietários, mas também podia responder à demanda de outros negociantes do bairro por baias para abrigo de carroças e animais, enfim, como espaço alugado. Dessa maneira, a construção ou o acréscimo no número de baias nas cocheiras existentes poderia ser uma resposta à demanda por esse tipo de espaço e, nesse caso, o negócio era $a$ própria cocheira. 
Outra possibilidade nesse mesmo sentido era o negócio não se restringir às cocheiras, mas também incluir itens relacionados a veículos e animais. Nesse caso, tratava-se de um serviço específico de transporte de mercadorias prestado aos comerciantes locais que não dispusessem de espaço físico para a própria cocheira ou de meios financeiros para arcar com todas as despesas acarretadas pela manutenção de veículos e animais. Essas despesas envolviam, no mínimo, a instalação em locais apropriados de animais sob as condições impostas pela legislação, incluindo a alimentação de cavalos, mulas e vacas, os cuidados com eventuais doenças e os serviços de ferradores de animais.

Diante da inexistência de registros ou pistas acerca do funcionamento das cocheiras e, consequentemente, do envolvimento dos veículos e animais ali estacionados com o comércio e distribuição de produtos, buscamos respostas na legislação que, direta ou indiretamente, incidisse sobre essas atividades.

Pelo menos desde meados do século XIX, o poder público procurava controlar as condições de funcionamento desses espaços através de leis, decretos e fiscalização direta. O Código Sanitário de I894 foi um dos primeiros a estabelecer regras mais rígidas sobre a localização de cocheiras e estábulos, assim como sobre as suas condições de higiene. Entre os pontos abordados pelo Código, destacam-se aqueles que dizem respeito à localização das cocheiras:

Artigo 335 - Devem ser prohibidas cocheiras e estabulos, nos pontos da cidade e povoações em que a população fôr densa, salvo os casos dos arts. 70 e $7 \mathrm{I}$ do capitulo $2 .^{\circ}$ com relação a cocheiras e estabulos particulares.

Artigo 336 - As municipalidades devem determinar em cada cidade a área onde taes installações devem ser prohibidas.

Artigo 337 - Os estabulos e cocheiras devem ficar sempre isolados e afastados das habitações.

Artigo 338 - Deverão ser collocadas a distancia de 8 metros pelo menos das ruas e praças publicas $^{17}$.

Já na segunda década do século XX, em I9II, o Capítulo I5 do Decreto n. 2.I4I dispunha que:

Artigo 380 - São proibidos os estabulos e cavallariças nos pontes das cidades o povoações em que a população fôr densa.

I7 SÃO PAULO (Estado). Decreto n. 233, de 2 de março de I894. Estabelece o Codigo Sanitario. Assembleia Legislativa do Estado de São Paulo. Secretaria Geral Parlamentar. Departamento de Documentação e Informação. Disponível em: <http://www.al.sp.gov.br/repositorio/legislacao/decreto/1894/decreto233-02.03.1894.html >. Acesso em: 20 jun. 2016 (grifos nossos). Foi mantida a grafia original dos documentos legais. 
Artigo 38I - As cavallariças e estabulos devem ficar á distancia minima de dez metros das ruas, praças publicas e habitações ${ }^{18}$.

Nos dois documentos, destacam-se os artigos 335 e 380 , respectivamente, que dizem respeito à proibição desses alojamentos em pontos da cidade em que a população fosse densa. A disposição da lei confirma-se pelos pareceres técnicos elaborados por fiscais e engenheiros da Diretoria de Obras e Viação da Prefeitura contidos nas solicitações das Obras Particulares, evidenciando a obrigatoriedade de essas edificações ficarem distantes de ruas, praças e habitações.

Poucos anos após o Decreto n. 2.I4I, em 9 de fevereiro de I9I8, foi promulgada a Lei n. 2.II7, regulamentando "o lançamento e a arrecadação do imposto sobre cocheiras”. " O teor dessa lei colocou alguns aspectos importantes para se conhecer mais profundamente o papel desempenhado por esses estabelecimentos. $O$ primeiro deles se relaciona ao fato de as cocheiras serem reconhecidas pela municipalidade como um tipo de negócio e assim estarem sujeitas ao pagamento de taxas. Conforme o artigo Io , "O imposto de industrias e profissões, sobre cocheiras, será lançado e arrecadado [...] independente de qualquer outro imposto ou modalidade de imposto a que o contribuinte esteja sujeito" ${ }^{\circ}$; a seguir, o art. $2^{\circ}$ estabelece que "o exercicio dessa industria continua a depender de alvará de licença”"

Independentemente da taxação que incidia sobre a cocheira, o proprietário também era taxado sobre as demais atividades a que a tal "indústria" estivesse relacionada. Por exemplo, se a cocheira estivesse a serviço de uma padaria, seu proprietário pagaria um imposto pela cocheira e outro pela padaria. Tudo indica que esse exemplo também pode ser estendido aos vendedores ambulantes de quitandas e armazéns, nos quais os negociantes em questão também pagariam duas taxas diferentes, uma pela cocheira, outra pela licença para a comercialização do produto em questão. $\mathrm{O}$ outro aspecto está contido no artigo $2^{\circ}$ da lei, que especifica que "O exercício dessa indústria [a cocheira] continua a depender de alvará de licença”"22. Nesse caso, independente do uso dado à cocheira - pessoal ou vinculado a um negócio -, seu proprietário deveria ter o alvará e, consequentemente, deveria pagar o respectivo imposto, independente "de qualquer outro imposto ou modalidade de imposto a que”23 ele estivesse sujeito.

I8 Idem, Decreto n. 2.I4I, de I4 de novembro de I9II. Reorganiza o Sistema Sanitario do Estado. Assembleia Legislativa do Estado de São Paulo. Secretaria Geral Parlamentar. Departamento de Documentação e Informação. Disponível em: <http://www.al.sp.gov.br/repositorio/legislacao/decreto/I9II/decreto2I4I-I4.II.I9II.html >. Acesso em: 20 jun. 2016 (grifos nossos).

I9 SÃO PAULO (Município). Lei n. 2.II7, de 9 de fevereiro de I9I8. Regula o lançamento e a arrecadação do imposto sobre cocheiras. Câmara Municipal de São Paulo. Legislação. Disponível em: <http://documentacao. camara.sp.gov.br/iah/fulltext/leis/L2II7.pdf >. Acesso em: 20 jun. 2016.

20 Ibidem (grifos nossos).

2I Ibidem (grifos nossos).

22 Ibidem.

23 Ibidem. 
As disposições revogadas pela Lei n. 2.II7, vinculadas à Lei n. 493 de 26/10/I900, dizem respeito aos artigos 35 e 36 respectivamente: "Tabella do imposto de licenças, estacionamentos e localisações" e "Perimetro para a cobrança do imposto de cocheiras”24. Já o § I을 do artigo 2I da Lei 790, de I7/II/I904, estabelecia o valor a ser pago pelas "Cocheira(s) de cavallares, muares ou vaccas, dentro do perimetro, para mais de dez animaes"25, além de definir que as cocheiras fora do perímetro nada pagariam.

Para aferir os "perímetros" indicados na legislação de I900 e I904, os atos n. 67I e 972 permitem acompanhar a inserção do bairro do Bexiga na lógica da cidade em seu conjunto. Já o Ato n. 67I, de I4/3/I9I4, que "dispõe sobre o reconhecimento de ruas" 26 da cidade, estabelece a Planta da cidade de São Paulo (I9I3) como parâmetro para o reconhecimento das ruas consideradas públicas. Dois anos mais tarde, o Ato n. $972^{27}$, de 24/8/I9I6, transferiu essa responsabilidade à Planta da cidade de São Paulo (I9I6), justamente o mapa sobre o qual se assentou a definição dos perímetros "central", "urbano", "suburbano" e "rural" indicados na Lei n. 2.II7.

Na planta de I9I6 encontram-se assim definidos os quatro perímetros da cidade: o perímetro central, demarcado em verde; o perímetro urbano, demarcado em rosa; o perímetro suburbano, demarcado em amarelo; e, a partir deste, o perímetro rural. Em I9I6 inseria-se o bairro do Bexiga (delimitado aqui com uma linha branca) no perímetro urbano e, dessa maneira, de acordo com o espaço delimitado pela Lei $\mathrm{n}$. 2II7, as taxas que incidiam sobre as cocheiras localizadas no bairro variavam de 50 mil réis (para aquelas que abrigavam até cinco animais ou cinco baias), 50 mil réis mais $5 \%$ do total (para aquelas com lotação entre seis e dez baias), Ioo mil réis mais $5 \%$ (para aquelas com lotação entre II e 20 baias), I50 mil réis mais IO\% (para aquelas com lotação entre 2I e 30 baias), e 200 mil réis mais IO\% (para aquelas com lotação para mais de 30 animais). Cabe destacar ainda que a Lei n. 2II7 só foi revogada pela Lei n. I4.IO6, de I2 de dezembro de 2005, quando há muito tempo as cocheiras haviam desaparecido do espaço urbano da capital paulista.

24 SÃO PAULO (Município). Lei n. 493, de 26 de outubro de I900. Fixa a despesa e orça a receita do municipio para o anno financeiro de $I^{\circ}$ de janeiro a 3I de dezembro de I9oı. Câmara Municipal de São Paulo. Legislação. Disponível em: 〈http://documentacao.camara.sp.gov.br/iah/fulltext/leis/L493.pdf 〉. Acesso em: 20 jun. 2016.

25 Idem, Lei n. 790, de I7 de novembro de I904. Orça a receita e fixa a despesa do municipio de S. Paulo para o exercicio de I905. Câmara Municipal de São Paulo. Legislação. Disponível em: <http://documentacao.camara. sp.gov.br/iah/fulltext/leis/L79o.pdf $>$. Acesso em: 20 jun. 2016.

26 Idem, Acto n. 67I, de I4 de março de I9I4. Dispõe sobre o reconhecimento de ruas. Câmara Municipal de São Paulo. Legislação. Disponível em: <http://documentacao.camara.sp.gov.br/iah/fulltext/actos/Ao67I-I9I4. pdf $>$. Acesso em: 20 jun. 2016.

27 Idem, Acto n. 972, de 24 de agosto de I9I6. Considera publicas, para todos os effeitos municipaes, todas as ruas, avenidas e praças, com os respectivos nomes, constantes da "Planta da cidade de S. Paulo", levantada pela Directoria de Obras e Viação. Câmara Municipal de São Paulo. Legislação. Disponível em: <http:// documentacao.camara.sp.gov.br/iah/fulltext/actos/A0972-I9I6.pdf >. Acesso em: 20 jun. 2016. 


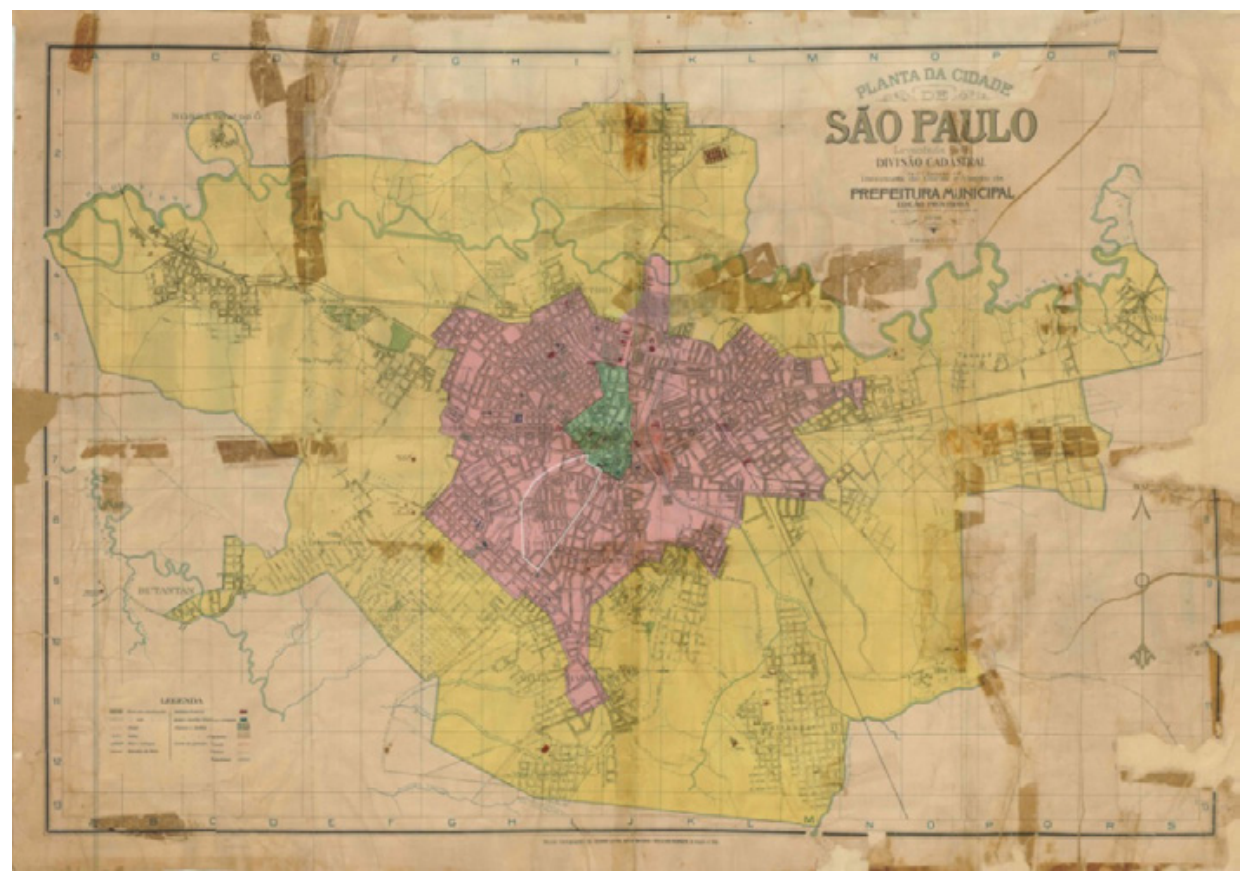

Figura I - Planta da cidade de São Paulo, I9I6. Divisão Cadastral da Directoria de Obras e Viação da Prefeitura Municipal. Fonte: Histórico Demográfico do Município de São Paulo. AHSP

Outro aspecto envolvendo, ainda que indiretamente, a presença das cocheiras referia-se à necessidade de normatização e controle da circulação de veículos pela cidade de São Paulo, em constante processo de expansão. Os antigos veículos movidos a tração animal operavam com uma lógica de tempos mais "lentos”, entrecruzando-se nas ruas da cidade com os modernos automóveis movidos a motor de combustão e representando o nítido símbolo do "atraso" e da "não civilidade” de uma cidade que cada vez mais se pretendia "cosmopolita" e "moderna. Por outro lado, além da fiscalização sobre a circulação (velocidade, locais de circulação e estacionamento etc.), também era necessário controlar as condições de funcionamento dos veículos (se motorizados ou movidos a tração animal); a competência profissional de seus condutores (através da concessão de carteiras de motorista mediante exames práticos específicos); o destino dos veículo (se de condução pessoal ou de carga) etc.

Três normas em especial abordaram essas questões: a Lei n. 2.264, de I3/2/I920, "sobre a inspeção e fiscalização do trânsito de veículos"28; o Ato n. I.426, de 26/4/I920, regulamentando alguns aspectos da Lei 2.264; e, por fim, a Lei n. 2.3I8, de II/9/I920, que veio detalhar os aspectos da Lei n. 2.264 relacionados aos veículos destinados ao

28 Idem, Lei n. 2.264, de I3 de fevereiro de I920. Dispõe sobre a inspeção e fiscalização do transito de veículos no municipio. Câmara Municipal de São Paulo. Legislação. Disponível em: <http://documentacao.camara. sp.gov.br/iah/fulltext/leis/L2264.pdf〉. Acesso em: 20 jun. $20 I 6$. 
transporte de passageiros. Dessas normas interessa o Ato n. I.426, particularmente os artigos 34, 36 e 90 :

Art. 34-Os veículos ficam divididos em duas especies, a saber: de condução pessoal e de carga, e serão numerados de acôrdo com o art. $I^{\circ}$ e seus paragrafos.

[...]Art. 36 - Os veículos destinados ao transporte de carga serão de três categorias, a saber: de aluguel, particulares e oficiais.

a. Os primeiros são os destinados a servir o publico, mediante remuneração ou frete, estacionando ou não nos pontos referidos neste Ato e terão na placa a letra A;

b. Os segundos são os destinados ao serviço exclusivo de seus proprietários e terão na placa a letra P;

c. Os terceiros são de propriedade da União, do Estado ou do Município e terão os emblemas respectivos ${ }^{29}$.

Os artigos mencionados acima esclarecem especialmente a questão relativa ao controle sobre a utilização dos veículos, se de transporte pessoal ou de carga. No caso do transporte pessoal, enquanto os veículos “de tração animada” ficavam dispensados do uso de placas indicativas, nota-se a obrigatoriedade do uso dessas placas nos automóveis movidos a motor de combustão, o que evidencia uma fiscalização mais rígida sobre os mesmos. Já no caso do transporte de cargas, as placas indicativas seriam sempre obrigatórias.

Por fim, o Capítulo IX, “Das empresas de transporte”, estabelece:

Art. 90 - Os donos, diretores ou gerentes das empresas de transporte de carga ou passageiros, deverão velar constantemente para que os condutores andem decentemente vestidos, os seus carros ofereçam a necessaria limpeza, segurança e conforto, os animais estejam ferrados e bem tratados $e$ as cocheiras mantidas com asseio ${ }^{30}$.

O Capítulo IX, ao se referir às obrigações dos proprietários e dirigentes das empresas de transporte de carga ou passageiros, remete aos espaços destinados ao abrigo dos veículos que nos interessam mais de perto - as cocheiras - e dá a medida de sua recorrência em certas áreas da cidade. Tratava-se de um tipo de "negócio" que envolvia "empresários" específicos.

Expostas as obrigações fundamentais a que estavam submetidas as empresas de transporte, espera-se ter completado o quadro legal que cercava a presença das cocheiras no espaço urbano. Ainda que nem todas as questões que envolvam as cocheiras e a

29 Idem, Ato n. I.426, de 26 de abril de I920. Regulamenta a Lei n. 2.264, de I3 de fevereiro de I920. Câmara Municipal de São Paulo. Legislação. Disponível em: <http://documentacao.camara.sp.gov.br/iah/fulltext/ actos/Ar426-I920.pdf >. Acesso em: 20 jun. 2016 (grifos nossos).

30 Ibidem (grifos nossos). 
suposta distribuição de produtos e serviços tenham sido respondidas, o conjunto de ações (e intenções) do poder público no sentido de controlar a circulação e o estacionamento de veículos forneceu pistas das possíveis funções desses estabelecimentos.

O Bexiga envolve uma área de grandes proporções, e as cocheiras estiveram presentes em praticamente todo o bairro, com exceção das ruas próximas ao centro, o que deve ser atribuído à proibição desse tipo de atividade em locais "em que a população fôr densa”, como estabelecido pelo Código Sanitário ${ }^{3 \mathrm{I}}$ de I894.

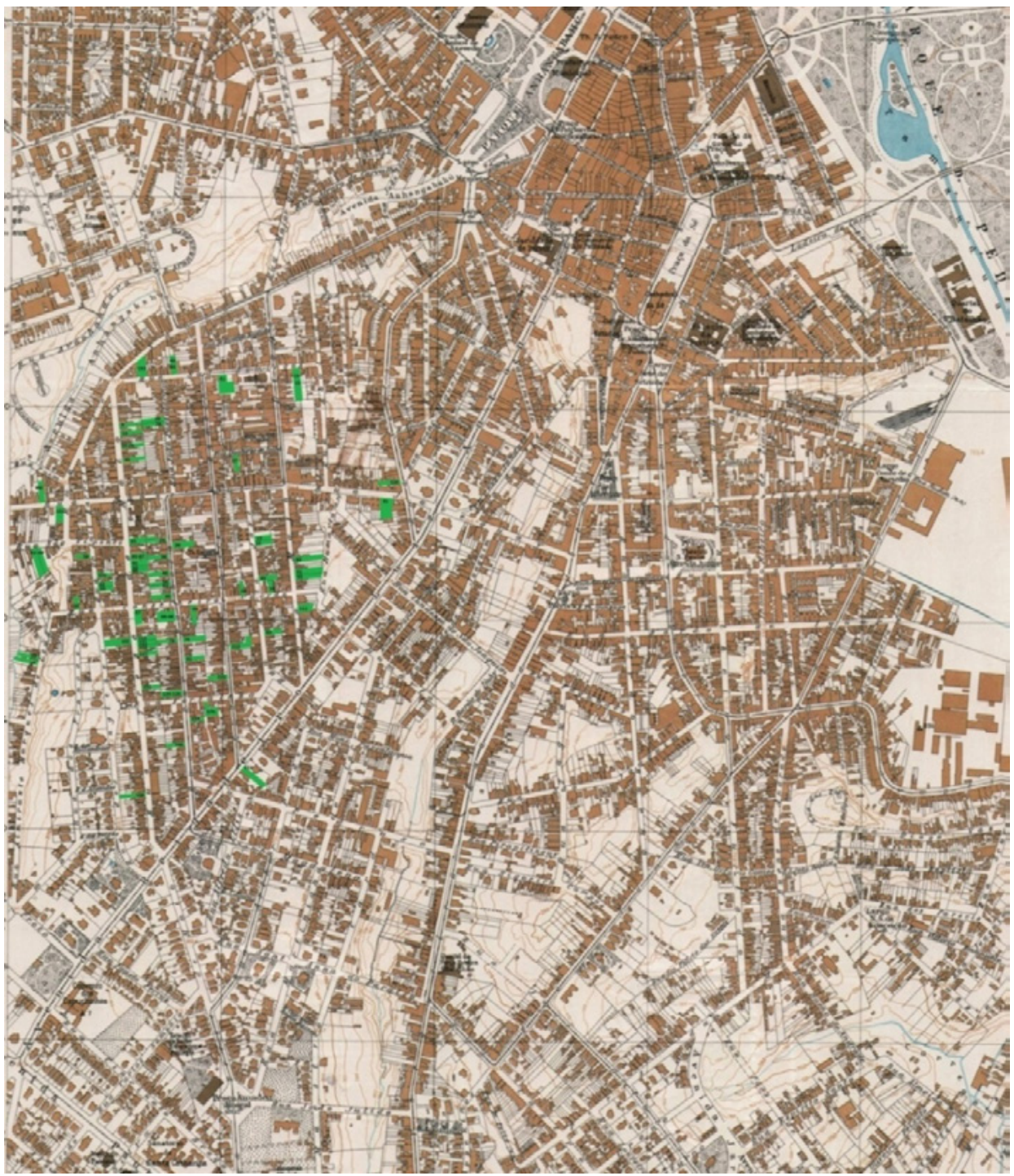

Figura 2 - Espacialização conjectural das cocheiras no bairro do Bexiga, entre I906 e I923. Planta Sara Brasil, I930. Fonte: AHSP

3I SÃO PAULO (Estado). Decreto n. 233, de 2 de março de I894, op. cit. 
A Planta Sara Brasil (figura 2) contém uma espacialização aproximada dos imóveis ocupados por esses estabelecimentos. Como muitas das cocheiras se mantiveram por todo o período investigado, a espacialização foi feita em uma única planta, independentemente do ano de sua ocorrência.

Embora o maior número de cocheiras estivesse concentrado nas ruas Treze de Maio e Rui Barbosa, elas se disseminaram por praticamente todas as demais vias do bairro. Com exceção das ruas mais curtas - as transversais São Domingos, Quatorze de Julho, Manoel Dutra, São Vicente, Conselheiro Carrão e Fortaleza - quase todas eram vias que desembocavam na Av. Brigadeiro Luís Antônio, principal eixo de articulação com o Centro e a Av. Paulista. Essa era uma artéria de extrema importância tendo em vista ligar o Centro aos bairros localizados ao sul da cidade - Morro dos Ingleses, Av. Paulista e Paraíso ${ }^{32}$-, e ao então município de Santo Amaro. No caso do Morro dos Ingleses e da Av. Paulista, tratava-se de bairros exclusivamente residenciais, cujos moradores constituíam uma clientela potencial para os comerciantes e prestadores de serviços estabelecidos nas ruas do Bexiga.

Diante desse cenário, ainda que não haja como confirmar concretamente a hipótese de que os produtos do comércio e dos serviços oferecidos por negociantes do Bexiga se destinassem a abastecer outros bairros, as informações recolhidas na Série Obras Particulares fornecem fortes indícios nessa direção. Além da construção de novas cocheiras, as solicitações também podiam envolver reconstrução, reforma, redução ou acréscimo de baias às construções mais antigas, razão pela qual os II3 processos originais reduziram-se a 80 casos. Desses casos, em dez ocasiões foi possível identificar os proprietários que alteraram suas cocheiras de maneira a aumentar ou reduzir o número de baias.

Interessante notar que uma parcela das reformas visando à redução do número de baias em cocheiras existentes ocorreu em fase de crise econômica, durante o período da Primeira Guerra Mundial. Alguns dos proprietários já haviam, inclusive, acrescido espaço para mais animais, contudo, em tempos de crise é provável que naquele momento optassem por diminuir as despesas. Um caso exemplar nesse sentido foi aquele de Francisco Volpe. Em I9Io, ele construiu uma cocheira que continha cinco baias na Rua Rui Barbosa n. 78; em I9I5, ele as reconstruiu, acrescentando mais uma baia; em I9I8, ele novamente reformou a cocheira, agora eliminando duas baias; no ano seguinte, I9I9, ele voltou a acrescentar mais uma baia à sua cocheira.

$\mathrm{Na}$ outra ponta dos proprietários de cocheiras, há aqueles que parecem ter tido mais sorte no negócio. Esse foi o caso, por exemplo, de Domingos Longo, que em I9II apresentou um "projeto de casa com armazém no alinhamento e cocheira nos fundos do terreno, com sete baias", na Rua Major Diogo n. 83. Oito anos depois, em

32 Isso para não falar no loteamento da Vila América, empreendimento lançado pela Companhia Edificadora de Villa América em I9I5. Seguindo-se a Av. Brigadeiro Luís Antônio, e ultrapassada a Av. Paulista, o loteamento envolvia os terrenos localizados exatamente abaixo dessa avenida, dando origem ao bairro atualmente conhecido como Jardim Paulista. 
I9I9, ele pediu licença para "reforma de cocheira, com redução de 27 para I6 baias"33. Em algum momento entre os anos que se passaram desde a construção da cocheira, Longo acrescentou 20 baias à cocheira existente. Agora, ele reduzia o número de baias e, consequentemente, de animais. De toda maneira, mesmo levando em conta a eliminação de onze animais, a sua posição privilegiada em relação aos demais proprietários de cocheiras é indiscutível.

Parece lógico pensar que, no caso das cocheiras com um alto número de baias, tratava-se de um negócio provavelmente voltado para o transporte de mercadorias. Do total das 80 cocheiras localizadas na série Obras Particulares, I6 solicitações estavam claramente associadas a algum tipo de negócio, mas em apenas nove ocasiões foi possível identificar o solicitante ou o endereço fornecido no Almanak Laemmert.

Em relação às cocheiras de maiores dimensões, foram identificados sete casos, distribuídos pelas ruas Major Diogo, Maria José, Rui Barbosa, São Domingos e Saracura Pequena. Foi possível verificar a tendência para aumento da construção ou reforma das cocheiras em determinados períodos, o que ocorreu principalmente nos anos de I9I5, I9I8 e I9I9. Em I9I5, mais proprietários encaminharam pedidos de licença para construção e/ou reforma de cocheiras, num total de I9 casos, sendo que ali se destacaram as cocheiras com duas baias (cinco) e as cocheiras com seis baias (seis). Na sequência, em I9I8, foram identificados I5 casos. Ali, a única categoria ausente é aquela das cocheiras com cinco baias, visto que as demais categorias foram todas contempladas. Já em I9I9 ocorreram I9 processos, nos quais se percebe a prevalência de cocheiras com uma baia (quatro), cocheiras com três baias (quatro) e cocheiras com sete ou mais baias (quatro).

Nesse momento, cabe retomar algumas informações fornecidas pela Lei n. 2.II734, especialmente o artigo primeiro, no qual estão discriminados os valores dos impostos sobre as cocheiras. Do total de solicitações encaminhadas à Diretoria de Obras entre I905 e I923, envolvendo a construção e/ou reforma de cocheiras, há referências a II casos com mais de 7 baias, sendo que apenas quatro superavam a lotação para II ou mais animais/baias e, nesses casos, o imposto a pagar era de cem mil réis, mais $5 \%$ do total. Nos casos restantes, em que o número de animais abrigados era inferior a dez, o imposto a pagar anualmente restringia-se a 50 mil réis ou 50 mil réis mais $5 \%$. Diante desses dados, verifica-se que a maioria absoluta das cocheiras pertencia a pessoas de pequenas e médias posses, o que provavelmente também se aplica aos supostos negócios envolvidos com essas cocheiras.

$\mathrm{Na}$ tentativa de ampliar o leque de dados sobre as cocheiras identificadas na série Obras Particulares, assim como preencher lacunas deixadas por aquela documentação, buscamos eventuais informações nos lançamentos do Imposto sobre

33 Obras Particulares, OP/I9II/O02.238, I7/05/I9II; OP/Doc.I8-CX.MI, IO/O2/I9I9, AHSP. Um ano depois do encaminhamento do processo junto à Diretoria de Obras, o serviço de Emplacamento da Prefeitura alterou a numeração do imóvel para o número 9I.

34 SÃO PAULO (Município). Lei n. 2.II7, de 9 de fevereiro de I9I8, op. cit. 
Comércio e Indústria efetuados nos anos de 1923 e I9335. Nesses documentos, o levantamento de todas as vias do bairro do Bexiga, distrito da Bela Vista, possibilitou a identificação inquestionável dos casos de cocheiras e garagens. E, embora o número desses estabelecimentos tenha se mostrado bastante reduzido em relação aos exemplares encontrados nas Obras Particulares, eles confirmaram se tratar de uma atividade produtiva específica que, como qualquer outra "indústria", estava sujeita a tributação.

No Imposto sobre Comércio e Indústria a primeira informação que ressalta aos olhos é a distinção entre as cocheiras de animais e as cocheiras de aluguel - as primeiras, supostamente voltadas ao abrigo de animais, e as segundas, mais especificamente ao aluguel de vagas para animais e provavelmente veículos. Contudo, essa distinção talvez não fosse tão rígida, pois no caso de Antônio Pansardi, proprietário de uma cocheira com nove baias à Rua São Domingos n. 4I, único a figurar nas relações de contribuintes de I923 e I933, em um ano a cocheira é de animais e no outro, de aluguel.

A transformação do serviço de cocheiras em outros negócios relacionados ao transporte ocorreu em duas ocasiões. A primeira foi aquela em que Domingos Bruno, que em I9I5 era proprietário de uma cocheira com seis baias na Rua Major Diogo e que consta no lançamento do imposto de I933 como proprietário de uma empresa de transportes. Possivelmente, a antiga cocheira de Bruno também se destinasse ao transporte de objetos, móveis, mercadorias etc., servindo aos comerciantes locais necessitados de veículos para entrega dos seus produtos. A segunda ocasião em que foi identificada uma mudança de "ramo" se refere a Luiz Monticelli, que possuía uma cocheira na Rua João Passalacqua n. 26 desde I9I2, ano em que pediu autorização para a construção da mesma sem definir o número de baias. Monticelli voltou a procurar a Diretoria de Obras para fazer alterações no imóvel em I9I5 e I9I9, indicando ora três, ora quatro baias. Em I933, ele aparece como proprietário de uma "garage de aluguel”, do que se infere que o espaço não serviria mais ao abrigo de animais e carroças, mas sim de automóveis. Embora não seja possível saber em que momento ele optou por essa mudança, a identificação de negócios sujeitos ao pagamento do Imposto sobre Comércio e Indústria naquele ano deixa claro que àquela altura o automóvel movido a motor de combustão era uma realidade inquestionável. Entre as 38 atividades ligadas ao transporte de pessoas e veículos, há 20 casos que de alguma maneira se vinculavam a esse tipo de veículo: garagens, oficinas mecânicas, postos de gasolina, vulcanização de veículos, comércio de automóveis, peças, pneus e óleos. Assim, é possível deduzir que Monticelli tenha procurado se aproveitar da nova moda para incrementar seu negócio...

Se nos anos apontados houve um aumento efetivo de processos envolvendo as cocheiras do bairro, a partir de I920 houve um decréscimo radical. A ausência de

35 Imposto do Comércio e Indústria (I923) - Distrito da Bela Vista, Diário Oficial do Estado de São Paulo, abril de I923. Disponível em: 〈http://www.jusbrasil.com.br/diarios/3773I08/pg-294I-diario-oficial-diario-oficial-doestado-de-sao-paulo-dosp-de-I8-04-I923>. Acesso em: I3 out. 20I4; e Imposto do Comércio e Indústria (I933) Distrito da Bela Vista, Diário Oficial do Estado de São Paulo, junho de I933. Disponível em: <http://www.jusbrasil. com.br/diarios/3926582/pg-33-diario-oficial-diario-oficial-do-estado-de-sao-paulo-dosp-de-Io-o6-I933/ pdfView $>$. Acesso em: 30 mar. 2015 . 
processos envolvendo cocheiras a partir desse ano certamente está relacionada à tendência de desaparecimento dessas tipologias. Embora alguns testemunhos iconográficos indiquem a presença das carroças nas ruas da cidade, pelo menos até os anos I940, cremos que a partir dos anos I920, o crescente processo de metropolização da cidade implicou a tendência de as cocheiras serem "expulsas" para "novos" arrabaldes. Por outro lado, a cobrança do Imposto de Comércio e Indústria de I933 indica que na década de I930 já se iniciava uma gradual substituição dos veículos a tração animal utilizados no transporte de cargas por aqueles motorizados.

\section{Conclusões}

Observamos anteriormente a profusão de pequenos e médios negócios distribuídos por três áreas distintas do Bexiga: o loteamento original, a Saracura e a área de influência da Av. Brigadeiro Luís Antônio. A partir dessas constatações, levantamos a hipótese central deste ensaio acerca da suposta função do bairro no abastecimento alimentar das áreas lindeiras. Porém, mais do que efetivamente comprovar essa hipótese, o objetivo deste estudo foi fornecer parâmetros para pensar algumas questões fundamentais para a compreensão do processo de urbanização da cidade - a redefinição dos espaços produtivos e sociais e as funções por eles exercidas no processo de expansão urbana ocorrido nas primeiras décadas do século $\mathrm{XX}$-, assim como problematizar as interfaces e interdependências de determinada área em relação ao espaço urbano mais amplo.

Assim, embora nossa hipótese não tenha sido efetivamente comprovada, acreditamos que nossa função primordial tenha sido alcançada.

SOBRE A AUTORA

SHEILA SCHNECK é doutora pela Faculdade de Arquitetura e Urbanismo da Universidade de São Paulo (FAU/USP).

E-mail: shschneck@gmail.com

\section{REFERÊNCIAS BIBLIOGRÁFICAS}

ALMANAK LAEMMERT. Editado nas Officinas Typographicas do Almanak Laemmert. Disponível em: <http://bndigital.bn.br/hemeroteca-digital>. Acesso em: 20 jun. 2016.

AMERICANO, Jorge. São Paulo naquele tempo (I895-I9I5). 2. ed. São Paulo: Carrenho Editorial/Carbono I4, 2004, p.IO3-II2.

BURKE, Peter. O que é história cultural?. 2. ed. Rio de Janeiro: Zahar, 2008. 
FAUSTO, Boris. A Revolução de I930. Historiografia e história. 7. ed. São Paulo: Brasiliense, I98I.

GRÜNSPUN, Haim. Anatomia de um bairro. O Bexiga. São Paulo: Cultura, I979.

LEPETIT, Bernard. Por uma nova história urbana. São Paulo: Edusp, 200 .

SÃO PAULO (Município). Acto n. Io, de I4 de maio de I894. Câmara Municipal de São Paulo. Legislação. Disponível em: 〈http://documentacao.camara.sp.gov.br/iah/fulltext/actos/AooIo-I894.pdf $>$. Acesso em: 20 jun. 2016.

. Lei n. 2.II7, de 9 de fevereiro de I9I8. Regula o lançamento e a arrecadação do imposto sobre cocheiras. Câmara Municipal de São Paulo. Legislação. Disponível em: <http://documentacao.camara. sp.gov.br/iah/fulltext/leis/L2II7.pdf >. Acesso em: 20 jun. 2016.

. Lei n. 493, de 26 de outubro de I900. Fixa a despesa e orça a receita do municipio para o anno financeiro de I ${ }^{\circ}$ de janeiro a 3I de dezembro de I90I. Câmara Municipal de São Paulo. Legislação. Disponível em: 〈http://documentacao.camara.sp.gov.br/iah/fulltext/leis/L493.pdf 〉. Acesso em: 20 jun. 2016.

. Lei n. 790, de I7 de novembro de I904. Orça a receita e fixa a despesa do municipio de S. Paulo para o exercicio de I905. Câmara Municipal de São Paulo. Legislação. Disponível em: 〈http://documentacao.camara.sp.gov.br/iah/fulltext/leis/L79o.pdf >. Acesso em: 20 jun. 2016.

. Acto n. 671, de I4 de março de I9I4. Dispõe sobre o reconhecimento de ruas. Câmara Municipal de São Paulo. Legislação. Disponível em: <http://documentacao.camara.sp.gov.br/iah/fulltext/actos/ Ao67I-I9I4.pdf $>$. Acesso em: 20 jun. 2016.

. Acto n. 972, de 24 de agosto de I9I6. Considera publicas, para todos os effeitos municipaes, todas as ruas, avenidas e praças, com os respectivos nomes, constantes da "Planta da cidade de S. Paulo", levantada pela Directoria de Obras e Viação. Câmara Municipal de São Paulo. Legislação. Disponível em: 〈http://documentacao.camara.sp.gov.br/iah/fulltext/actos/A0972-I9I6.pdf >. Acesso em: 20 jun. 2016.

. Lei n. 2.264, de I3 de fevereiro de I920. Dispõe sobre a inspeção e fiscalização do transito de veículos no municipio. Câmara Municipal de São Paulo. Legislação. Disponível em: <http://documentacao. camara.sp.gov.br/iah/fulltext/leis/L2264.pdf >. Acesso em: 20 jun. 2016.

. Ato n. I.426, de 26 de abril de I920. Regulamenta a Lei n. 2.264, de I3 de fevereiro de I920. Câmara Municipal de São Paulo. Legislação. Disponível em: <http://documentacao.camara.sp.gov.br/iah/ fulltext/actos/Ar426-I920.pdf >. Acesso em: 20 jun. 2016.

SÃO PAULO (Estado). Decreto n. 233, de 2 de março de I894. Estabelece o Codigo Sanitario. Assembleia Legislativa do Estado de São Paulo. Secretaria Geral Parlamentar. Departamento de Documentação e Informação. Disponível em: <http://www.al.sp.gov.br/repositorio/legislacao/decreto/I894/decreto-233-02.03.I894.html >. Acesso em: 20 jun. 2016.

. Decreto n. 2.I4I, de I4 de novembro de I9II. Reorganiza o Sistema Sanitario do Estado. Assembleia Legislativa do Estado de São Paulo. Secretaria Geral Parlamentar. Departamento de Documentação e Informação. Disponível em: <http://www.al.sp.gov.br/repositorio/legislacao/decreto/I9II/decreto-2I4I-I4.II.I9II.html >. Acesso em: 20 jun. 2016. 